\title{
14 Şubat Sevgililer Günü Televizyon Reklamlarının Göstergebilimsel Çözümlemesi
}

Elif ŞEŞEN*

\section{$\ddot{O} \mathbf{z}$}

İhtiyaç ve tüketim arasındaki ilişkinin değiştiği, bireyler için tüketimin ihtiyacı karşılamaktan farklı anlamlara geldiği ve bir kimlik göstergesine dönüştüğü günümüz tüketim toplumunda, değişen olgulardan biri de aşk ya da sevgi kavramıdır. Aşkın sürekli gösterilmesi gereken bir şey haline gelmesi ve ayrıca tüketim nesnelerinden geçerek anlatılması ve anlaşılması bu sürecin temel özelliklerinden biridir. Aşk ile tüketim arasındaki ilişkiyi yeniden kuran mecraların başında ise reklamlar gelmektedir. Tüketimle yönlendirilen aşkın toplumsal algısı, 14 Şubat Sevgililer Günü reklamları aracılığıyla yeniden üretilmektedir. Hediye alarak sevdiğini mutlu etme düşüncesinin reklam mesajları ile nasıl dolaşıma sokulduğunu ortaya koymayı amaçlayan bu çalışmada, 13 Şubat 2019 tarihinde 6 ulusal televizyon kanalında prime time zaman diliminde yani 21.00 ile 23.00 saatleri arasında yayınlanan 14 Şubat'a özel reklamlar incelenmektedir. Toplam 11 reklamın göstergebilimsel yöntemden hareketle analiz edildiği çalışmada, reklam söylemini kuran göstergeler ve bu göstergelerin anlamlandırılmasını sağlayan gönderge sistemleri incelenmiştir. Reklamların ortak vaadinin Sevgililer Günü’nde alınacak hediyenin aşkın göstergesi olduğu yönündedir.

Anahtar Kelimeler: 14 Şubat Sevgililer Günü, Reklam, Tüketim, Mit, Göstergebilim

\section{Semiotic Analyis of 14th February Valentine's Day Television Advertisements}

\begin{abstract}
In today's consumer society, where the relationship between the need and consumption changes for individuals consumption has a different meaning and turns into an identity sign, one of the changing phenomenon is love. The main characteristics of this process are that love has become something to be shown continuously, and that is explained and understood through consumption objects. Advertising is one of the leading channels that reconstructs the relationship between love and consumption. The social perception of love driven by consumption, is reproduced through 14th February Valentine's Day advertisements. In this study, which aims to reveal how the idea of making happy his/her lover by buying a gift circulating by advertising messages, special advertisements for Valentine's Day which featured on 6 national television channels on February 13, 2019 during the prime time period, that is, between 21:00 and 23:00, were examined. In the study in which a total of 11 ads were analyzed based on the semiotic method, the signs establishing the discourse and the referrent systems that give meaning to these signs were examined. The sharing promise of advertisements is that the gift bought on Valentine's Day is a sign of love.
\end{abstract}

Keywords: 14th February Valentine's Day, Advertisement, Consumption, Myth, Semiotic

Geliş/Received: 10.08 .2020

Kabul/Accepted: 22.06 .2021

* Bu çalışma, insanlardan veri ve örnek toplamayı gerektiren, anket, inceleme, alan çalışması ve deney içeren araştırmalar kapsamına girmediğinden etik kurul onay belgesi gerektirmemektedir.

\footnotetext{
* Doç. Dr., Niğde Ömer Halisdemir Üniversitesi, İletişim Fakültesi, Halkla İlişkiler ve Reklamcılık Bölümü, elifsesen@gmail.com, ORCID: 0000-0002-8513-9647.

(Makale Türü: Araştırma Makalesi)
} 


\section{Giriş}

Beynelmilel (2006) filminin bir sahnesinde, "Senin kız arkadaşın da vardır şimdi üniversitede?" diye soran esas kıza, esas oğlan "Yoktur, küçük burjuva alışkanlıkları bunlar. Hem artık devrimci oldum ben." diye cevap verir. Bunun ne anlama geldiğini bilmeyen kızsa "Çok iyi yapmışsın vallahi.” diye karşılık verir. Ne de olsa aşık olmak ya da flört etmek, parası ve boş zamanı olan burjuvalara hitap eden bir şeydir. Ancak postmodern tüketim toplumunda durum böyle değildir. Lefebvre'nin (1998) tüketimi yönlendirilmiş ya da örgütlenmiş toplum olarak tanımladığı tüketim toplumunda, tüketim artık gerçek olduğu kadar hatta belki de gerçekten çok, simgeseldir. Çağdaş tüketim kalıpları sembolik anlam ve değer sistemleri üzerine kuruludur (Bocock, 1997: 56) ve reklamın da işlevi her türlü günlük ya da kültürel değer ve olguları tüketime aktarmaktır. Tüketim toplumuna olumlu bakış açısı bu toplumu "kapitalist sistemde hızlı bir ekonomik gelişme sağlayarak insanların her türlü ihtiyacını karşılayan toplum" (Odabaşı, 2006: 19) olarak görürken olumsuz ya da eleştirel bakış açısına göre ise ekonomik büyüme ve üretim bolluğunu gelişme ile eşitleyen bu toplum aslında ayrımcılığın işaretleriyle dolu, göstergelerden beslenen (Baudrillard, 2004: 51) bir toplumdur. İhtiyaç kavramının anlamının değiştiği tüketim toplumunda, insanların ihtiyaçları hiçbir zaman tam olarak karşılanmamakta ve aslında ürünleri değil bu ürünlerin sahte imaj ve göstergelerini tüketen insanların ihtiyaçları, hayalleri, umutları ve beklentileri sömürülmektedir. Tüketimin, bireylerin kimliklerini inşa ettikleri bir araç haline gelmesiyle tüketilen malların kişi için anlamı, içinde yaşadığı toplumsal ilişkiler ağıyla bağlantılı şekilde oluşturulan, gündelik yaşam pratiklerine yansımış bir tür dile dönüşmüştür.

Barthes'a (1998: 168) göre bu dil içindeki göstergelerden oluşan yapı dizgelerinde, nesneler anlam aktarmaktadır yani bir nesne tüketim aracılılığıyla başka bir şeyin (duygu, hayal, kimlik, prestij, saygınlık, zenginlik, lüks, aşk, sevgi vb) yerine geçmektedir. Tüketim toplumunda, toplumun ve onun dekorunun, yani modernliğin temel ürünü haline gelen gündelik yaşam içinde kadın-erkek ilişkileri de değişmiştir. İnsanın davranışlarını, kişiliğini, ilişkilerini, zevk algısından, estetik yapısına kadar her şeyini belirleyen bu kültür içinde aşk, hem toplumun tüm kesimlerine yayılması gereken bir şey gibi anlatılır hale gelmiş hem de her meta gibi pazara çıkmıştır. Bu sürecin simgelerinden biri de tüketim toplumunun vardığı son nokta, tüketim çılgınlığı, tüketim tuzağı gibi sıfatlarla anılan ancak her şeye rağmen etkisinde kaldığımız Sevgililer Günü'dür. Aşkın toplumsal algısı, tüketim bağlamında Sevgililer Günü ve bu güne özel reklamlar aracılığıyla yeniden üretilmektedir. Yılbaşı, bayram gibi diğer özel günlerde olduğu üzere reklamlar, Sevgililer Günü'nde neler alınması ya da yapılması gerektiğine, bu günün nasıl kutlanması gerektiğine dair ipuçlarını hatırlatma görevini üstlenmektedir.

Küresel olarak şekillendirilmiş aşk kavramının medya ve reklam mesajları ile nasıl dolaşıma sokulduğunu sergilemeyi amaçlayan bu çalışma, 2019 yılında Sevgililer Günü’nden bir 
gün önce reklamların şahikaya ulaştığı 13 Şubat'ta ulusal televizyon kanallarında yayınlanan bu güne özel reklamları incelemektedir. Çalışmada, Sevgililer Günü reklamlarındaki aşk ve tüketime dair mitler ve imgeler göstergebilimsel yöntemden hareketle çözümlenerek bu güne özel olarak yayınlanan reklamlarda tekrar edilen sembollere dair genel bir tablo ortaya konulmaya çalışılacaktır.

\section{Aşk, Tüketim Kültürü ve Reklam}

Aşk1 tüm dürtülerin en güçlüsü olarak gören Schopenhauer (2011: 35) aşkın insan hayatında hayat sevgisinin yanı başında durduğunu yazmaktadır. Romanlar, şiirler, şarkılar, filmler ve reklamların aşka dair algımızı şekillendirmede etkili olduğuna dikkati çeken Büyükdüvenci (2001: 172) aşkın anlamının ve ifade araçlarının zamanla değiştiğini ve günümüzde metaların sevginin göstergesi olarak sunulduğunu söylemektedir. Belirli mal ya da hizmetlere sahip olmanız ya da size hediye edilmesi durumunda mutlu olacağınızı söyleyen reklam mesajları ile dolu tüketim toplumunda aşk, bir sevgili ya da eşin, sevgisinin ifadesi olarak belirli bir ürünü satın almasını gerektiren ticari bir işleme, bir alışverişe dönüşmektedir. Miller’e (2010: 181) göre tüketim kültürünün yerleşmesi aşkı satın alınabilen bir meta haline getirmiştir. Tüketim kültürünün, mal ve hizmetlerin gösterge işlevinin fayda işlevinden daha önemli hale gelmesiyle karakterize olduğunu belirten Bauman'a (1997: 83) göre metaların mübadele değerinin ortadan kalkmasıyla alınıp satılan ve tüketilen şey, göstergeler haline gelmiştir. Göstergelerin sistemli bir şekilde güdümlendiği (Baudrillard, 2014: 240) tüketim toplumunda nesneler bir bağlam içinde tüketiciye sunulmaktadır. Örneğin bir firın sadece yemek pişirmeye yarayan bir nesne olarak değil, yeni ve modern diğer beyaz eşyaların da sergilendiği bir mutfağın parçası, lüks ve modern bir yaşam tarzının sembolü olarak gösterilmektedir.

Satış, mübadele ve kâr amacı güden ücretli emek ve meta üretimine dayanan (Marshall, 2005: 382) kapitalist sistemde sürekli yapılan tüketim propagandası, modern yaşamın ruhsal yalnızlığını hedef alır ve modern insanın bunalımlarına çare olarak da tüketimi gösterir (Lasch, 2006: 125). Üstelik kapitalist sistemin harekete geçirdiği tüketim seferberliği giyimden dekorasyona, spor alışkanlıklarımızdan dinlediğimiz müzik türüne, yeme içmeden boş zaman etkinliklerimize kadar gündelik hayatımızın hemen her anını içine alan geniş bir alanda çalışmaktadır (Bauman, 2014: 77). Satın almanın ve tüketimin büyüsü tüm bu alanlarda sürekli olarak üretime çevrilmelidir ancak bu da tüketiciyi asla kazanamayacağı bir oyuna dahil eder. Nitekim Baudrillard (2013) da Üretimin Aynası'nda, ihtiyacın artık içgüdülerce değil metalar arasındaki ilişkilerce belirlendiği, her gün daha fazla gösterge ve imajlarla dolup taşan tüketim toplumunda tüketicilerin asla tatmin olamayacağını söylemektedir. Çünkü bireylerin sahip olduklarından tatmin olması tüketimi sekteye uğratır. Modern tüketim kültürünün temel özelliklerini maddileşme, estetikleşme ve sürekli farklılaşma olarak sayan Zorlu (2003:7) tüketim 
kültürü ile bireysel beğeniler ve yaşam tarzlarının yanı sıra toplumsal değerlerin de ifade edildiğini vurgulamaktadır. İnsanların gerçek ihtiyaçları yerine statü ya da yenilik arama, ilgi uyandırma gibi saikler ile tüketimde bulunduğu bir sistem olarak tüketim kültürü, nesnelerin imgesel düzeyde anlamlandırılmasına dayanmaktadır. Featherstone (1996: 145) aslında sıradan ya da gündelik nesnelerin lüks, güzellik ve cazibe gibi arzu edilen şeylerle bağlantılandırıldığını ve bu süreçte metalaşan nesnelerin gerçek işlevlerinin giderek önemsizleştiğini söylemektedir. Türkiye'de de 1960'lardan başlayarak artan şekilde yerleşen tüketim alışkanlıkları ile tüketim, bireyin kimliğini ifade etmesinde (Topay ve Erdem, 2019: 173) önemli bir araç haline gelmiştir. Toplumsal başarı, her alanda yüksek tüketim ile özdeşleşirken, sevgi, dostluk, aşk kısaca tüm insani ilişkiler, ticareti yapılabilen birer nesne olmuşlardır (Bayhan, 2011: 233).

Aşk, üzerinde tıptan büyücülüğe uzanan geniş bir sektörel ağın yükseldiği (Yıldız, 2013: 192) bir duygudur. Günümüz tüketim toplumunda ise bir duygu olarak kalmamakta romanlar, filmler, diziler, reklamlar ile metaforik ve mitsel bir söyleme dönüştürülmektedir. Özellikle reklamlar kullandıkları anlam kurma stratejileri ile bu söylemin önemli bir parçasıdır. Gündelik hayatı yeniden büyüleyen ve inşa eden reklam, sıradan ürünlere yeni anlamlar katarak sihirli imgelere yani mitlere dönüşmesini ve böylece tüketicinin ürünün gerçek ederinin çok daha üzerinde bedeller ödemeye bireylerin razı edilmesini sağlamaktadır. Reklam, ideolojik işlevini inşa ettiği mitler sayesinde yerine getirmektedir (Kükrer, 2010: 29). Bu mitler, bireylere reklamlarda kurulan simgesel anlamlarla donatılmış kimliklere ancak tüketim aracılığıyla sahip olunabileceği düşüncesini aşılamaktadır. Satın alma eylemi ile prestij, saygınlık ya da kimlik kazanma arzularını birbirine bağlayan reklam, mevcut toplumsal değerlerden yola çıkarak yapay konumlar yaratır ve bedelini ödemek şartıyla bu konumlara sahip olabileceklerine bireyleri inandırır. Wernick'in (1996: 63) vurguladığı gibi reklam sadece bir metaya ihtiyaç duymamız gerektiğini söylemekle kalmaz o metanın inşa edilmiş sembolik anlamını da devreye sokar. Bir ürün ya da hizmetten çok daha fazlasını başarı, haz, sevgi gibi duyguları, değerleri, imgeleri satan reklam, vaadini basitçe "bu ürünü alırsan memnun kalacaksın" şeklinde değil, "sadece bu ürünü alırsan mutlu olacaksın ve insanlar seni kıskanacak" şeklinde ortaya koyar.

Nesneler ile ilgili ifadeleri, tüketici ve insan ilişkileri tarzında ifadelere çeviren (Dyer, 2010: 168) reklam söyleminde yapılan, temel olarak bir şeyin anlamını başka şeye yükleyerek değeri ürünle bağlantılandırmaktır. 'Pırlanta ebedidir' sloganlı reklamı örnek gösteren Williamson (2001) pırlantanın artık bir taş ya da mineral olarak değil, insani ilişkiler bağlamında bir gösterge olarak anlamlandırıldığını söylemektedir. Belki pırlanta aşkı satın alamaz ama reklam bize ebedi aşka benzetilen pırlantanın aşkı sağlayabileceğini ima eder ve böylece reklamın dilinde insanlar ile nesneler yer değiştirir. Reklamın temel amacı, hedef olarak belirlenen tüketici kitlesi üzerinde belirli bir etki oluşturmak ve bu kitlenin düşünce ve alışkanlıklarını etkileyerek satın 
almaya yönlendirmektir (Kocabaş ve Elden, 2004: 21). Ancak reklam, tüketicinin değerleri ve yaşam tarzı ile ilişki kurup zihninde anlamlı bir çağrışıma yol açarsa bu hedefine ulaşabilir. İşte bu nedenle reklamlar genellikle ürünün özellikleri hakkında değildir. Reklamlarının ilgili olduğu asıl şey tüketicinin özelliğidir. Reklamlardaki film yıldızları ya da sporcular, romantik anlar, güzel evler, lüks mekanlar aslında ürünle ilgili bir şey söylemez. Bunlar ve daha birçok reklam imgesi tüketicinin hayalleri, duyguları, korkuları ve fantezilerine seslenir. Postman'a (2006: 192) göre zaten bir reklamcının bilmesi gereken şey ürün hakkında neyin doğru olduğundan çok, ürünü satın alacak tüketici ile ilgili neyin yanlış ya da eksik olduğudur.

\section{Reklamlarla Metalaşan 14 Şubat Sevgililer Günü}

Anneler Günü, Babalar Günü, Sevgililer Günü gibi özel günlerin tüketim toplumunun kurucuları tarafından tüketimi kamçılama amacıyla icat ve ilan edildiğini belirten Ersoy (2008: 150) bu durumun sadece tüketim harcamalarında değil insanların zihniyet dünyalarında da değişime sebep olduğuna dikkati çekmektedir. Erdoğan ve Alemdar (2005: 167) da kapitalist pazarın ihtiyaçlarını karşılamak için bir tür promosyon olarak kullanılan özel günlerde tüketicilerin duygularının istismar edilmesiyle yaratılan yeni tüketim kültürü yoluyla insanların sürekli harcama baskısı altında tutulduklarını söylemektedirler. Yılbaşından anneler gününe, babalar gününden sevgililer gününe özel(leştirilen) günlerin kutlanmasına dair ritüeller medya ve reklamlar aracılığıyla aktarılmaktadır. Kültürel alışverişi hızlandıran küreselleşme toplumları daha yakın hale getirmekle beraber aynı süreçte birbirine benzeşmelerine yol açmaktadır (Ünalan ve Doğan, 2019: 4). Batı dünyasından tüm dünyaya yayılan ve küreselleşen bu özel günlerde, pazarlama çabalarının da bir sonucu olarak hediye vermek olmazsa olmaz bir durum halini almıştır (Şeker, 2019: 870). Hediye geleneğini şekillendiren temel dinamik haline gelen medya; reklam mesajları aracılığıyla ulusal, yerel ve kişisel çeşitliliği ortadan kaldırarak küresel kültürel standardizasyonu gerçekleştirmede önemli bir rol oynamaktadır.

Hediye verme sebepleri çeşitlidir ve resmi protokol kurallarından bayramlara, özel günlerden anlık davranışlara kadar değişebilir. Mauss (1954) hediye değişimini ekonomik, hukuki, ahlaki, estetik, dini ve mitolojik anlamlar içeren toplumsal bir olgu olarak görür. Hediye, elde olmayanın verilmesi bağlamında düşünüldüğünde aşkla sevgiyle ilişkilendirilmektedir (Akay, 1999: 89). Hediyeleşmenin toplumsal ve ekonomik sonuçları da önemlidir (Rupp, 2003). Hediye vermenin neredeyse bir zorunluluk haline geldiği özel günlerden biri de Sevgililer Günü'dür. Son y1llarda ülkemizde de popüler hale gelerek kutlanan Sevgililer Günü tüketime endekslenmiş özel bir gün olarak kapitalist pazardaki yerini almıştır.

Başlangıcına dair çok sayıda hikâye olan Sevgililer Günü'ne dair efsanelerden en fazla dile getirilenlerinden biri, Roma İmparatorluğu zamanında evliliğin yasaklandığı bir dönemde Valentinus adlı bir din adamının gizlice çiftleri evlendirdiği ve bunun açığa çıkmasıyla 14 Şubat 
günü öldürüldügüne, onun ölüm gününün de hatırasını yaşatmak adına aşk ve sevgi günü olarak kutlanmaya başlandığına dayanır (Calesta, 2006: 18). Sevgililer Günü’nün romantik sevgi ile ilişkilendirilmesi Orta Çağa kadar gitmektedir (Siddiqui, 2016: 171). 19. yüzyılın ikinci yarısında İngiltere'den ABD'ye geçen Sevgililer Günü, 20. yüzyılda neoliberal ekonomiyle beraber gelen toplumsal değişimle dünyaya yayılır (Brosius, 2012). Aşk ve sevgi gününün bir tüketim çılgınlığına dönüşümü ise 1980'lerden sonra olmuştur. Ekonomik değerinin farkına varılmasıyla 14 Şubat, kapitalizmin manivelası kültür endüstrisi tarafından kutsanan ve reklam çabalarının en üst düzeye çıkarıldığı günlerden biri haline gelmiştir. İnsanlar arasındaki duygular ve ilişkiler de dahil olmak üzere modern insanın yaşamının her noktasına müdahale ederek her şeyi ticarileştiren kapitalizm, Çubuklu'ya (2007: 98) göre aşk ve sevgiyi de popülerleştirerek bir meta olarak sunmaktadır. Sevginin sürekli ifade edilmesi ve gösterilmesi gerektiği düşüncesinin bilinçli bir şekilde yaygınlaştırıldığı Debord'un (1996) adlandırmasıyla gösteri toplumunda, duygular ancak metalardan geçerek ifade edilebilmekte ve hediyenin parasal değeri duygunun yoğunluğunun ölçüsü haline gelmektedir. Medyanın parlattı̆g 14 Şubat, özellikle erkeklerin eşlerine ya da sevgililerine hediye almalarının bir dayatma haline geldiği, aşkın ya da sevginin ancak bir hediye ile ispatlanabileceği bir tarihe karşıllk gelmeye başlamıştır. Sevgililer Günü başlangıcındaki dini bağlamından farklı şekilde postmodern tüketim kültürü tarafından kutsanan ve ticari olarak inşa edilmiş bir gündür (Kimura ve Belk, 2005). Sevgililer Günü, tebrik kartları, hediyeler, özel partiler ve tatiller gibi çeşitli tüketim etkinlikleriyle kutlanır. Bu tür kutlama etkinlikleri için günler önce yapılan harcamalar bu günü küresel pazar için vazgeçilmez hale getirmektedir. ABD Ulusal Perakende Federasyonu'nun (National Retail Federation) 2019 Yılı Sevgililer Günü Harcama Anketine (Annual 2019 Valentine's Day Spending Survey) göre, sadece bugün için yapılan hediye alışverişinde kişi başı harcama 161 dolar ve toplam harcama ise 20 milyar dolardan fazlaydı. Ülkemizde de özellikle 1990'lardan itibaren hediyelerin fiyatı ve çeşitliliği artmış, alışveriş süreci abartılı hale gelmiştir. Aslında bu durumda, Kozanoğlu'nun (1995: 168) sözleriyle pop çağı ateşi ile yanan Türkiye'de, daha önce hiç bu kadar sık söylenmeyen sevgi sözlerinin içini boşaltıp bir dolgu haline getiren piyasa mantığının da önemli bir rolü vardır.

Pek çok toplumsal öğreti ve pratikle birleşen Sevgililer Günü, popüler kültürün en açık ve en pembe rengi olarak (Arık, 2004) kapitalizmin metalaştırdığg ve fetişleştirdiği, aşkın tüketim ile özdeşleştirildiği bir kültürel gösterge haline gelmiştir. Sevgililer Günü’nde insanların birbirlerine hediye alma zorunluluğunu hissetmeleri kitle kültürünün tezahürü olarak değerlendirilebilir (Canöz, 2015: 141). Bugüne özel hazırlanan reklamlarla da sevginin ekonomik araçlarla ifade edilmesi meşrulaştırılarak özendirilir. Vannini'ye (2004: 171) göre, Sevgililer Günü'nde metaların romantikleşmesi ve romantizmin metalaşması olmak üzere birbirine bağlı iki süreç söz konusudur. Başta reklamlar olmak üzere medya çeşitli araçlarla, bir gösteri olarak aşk 
fikrini iletir. Metaların romantikleşmesi, medya belirli davranış ya da ürünleri romantizmin göstergesi olarak sunduğunda ortaya çıkar. Örneğin ikisi de çiçek olmasına rağmen kaktüs, romantik değildir ama kırmızı gül, romantiktir ya da lüks bir restoranda mum ışığı eşliğinde yenen bir akşam yemeği romantiktir ama fastfood restoranındaki öğle yemeği romantik değildir. Romantizmin metalaşması ise evlilik teklifi için tek taş yüzük alınması gibi belirli tüketim pratiklerinin bireylerin zihninde aşkın sembolü olarak yerleştirilmesinin sonucunda ortaya çıkar.

Sevgililer Günü’nün tüketim ve reklam açısından yeri ve rolüne dair çeşitli çalışmalar yapılmıştır. Minowa, Khomenko ve Belk'in (2011: 45) Sevgililer Günü hediyelerinde cinsiyete dayalı ritüellerin; tüketim ideolojisi ile zamanla değişen toplumsal değerler ve cinsiyet rollerini yansıttığını ortaya koymuşlardır. Close ve Zinkhan (2006: 359) bu güne özgü tüketici davranışlarının başında tek taş yüzük, kırmızı gül, çiçek, oyuncak ayı, akşam yemeği gibi hediyeler verilmesinin geldiğini belirtmektedirler. Rugimbana, Donahay, Neal ve Polonsky'e (2003) göre bu hediyelerin seçiminde reklamların yarattığı atmosfer önemli bir faktördür. Sevgililer Günü reklamlarında genel olarak bir kadının ancak erkeği için özel olarak hazırlanarak güzel görünmesi halinde, bir erkek ise kendisinden beklenen romantik davranışları gösterirse “ideal” bir sevgili olabileceği fikri yerleştirilmeye çalışılır. Ülkemizde yapılan çalışmalardan Atar, Şener ve Onay’ın (2016) Sevgililer Günü için hazırlanan dergi reklamlarını inceledikleri çalışmalarında, en çok reklamı yapılan ürünlerin tek taş ve pahalı mücevherler olduğunu belirterek bu durumu sevginin büyüklüğünün hediyenin pahası yani fiyatıyla gösterme isteğiyle açıklamaktadırlar. Aydın ve Akcan'ın (2017) Sevgililer Günü hediyelerini inceledikleri çalışmalarında, bazı reklamların sevdiğini mutlu etme amacını öne çıkarmakla birlikte hemen tüm reklamların daha fazla tüketim ile daha mutlu olmayı vadettiğini belirtmektedirler. Gazete reklamlarını inceleyen Adalı Aydın (2016) da çalışmasında incelenen reklamlarda belirli ürünlerin kullanılarak daha aşık ya da daha mutlu olunacağı ile belirli ürünlerin satın alınarak iyi bir sevgili olunacağı mitlerinin sıkça tercih edildiğini ortaya koymuştur. Denilebilir ki reklamlar hediyenin maddi değerini öne çıkaracak şekilde kurgulanmaktadır.

\section{Yöntem}

Bu çalışmanın amacı, markalar tarafından Sevgililer Günü’ne özel olarak hazırlanan ve 2019 yılında ulusal kanallarda yayınlanan televizyon reklamlarının göstergebilimsel çözümlemesini yapmaktır. Nitel araştırmalarda sıkça kullanılan amaçlı örneklem yöntemine başvurulmuştur. Amaçlı örnekleme belirli bir hedefe ulaşmak için araştırılan konu kapsamında incelenen olguyu açıklamaya yardımcı olacak ve belirli niteliklere sahip nesne, birey, mekân ya da örneklerin seçimine dayanır (Marshall, 1996: 523). Çalışmada öncelikle bir medya takip ajansından 2019 yılında Sevgililer Günü’nün bir gün öncesinde yani 13 Şubat 2019 tarihinde 
ATV, Fox TV, Kanal D, Show TV, Star TV, TRT 1 olmak üzere ulusal televizyon kanallarında ${ }^{\dagger}$ prime time saatleri (21.00-23.00 arası) arasındaki programlarda yayınlanan reklamların listesi edinilmiş, tekrarlar çıkarılmıştır. 14 Şubat Sevgililer Günü'ne özel 13 reklam tespit edilmiş ve sonraki aşamada reklam videolarına, video paylaşım kanalı Youtube'dan ulaşılmaya çalışılmış olup 2 reklamın (Colins ve Lizay) videosuna ulaşılamamıştır. Dolayısıyla Sevgililer Günü’ne özel olarak hazırlanmış 11 reklam, araştırmanın örneklemini oluşturmaktadır. Çalışma kapsamındaki reklamlar, göstergebilimsel yöntemden hareket eden Chapman'1n (1986) Reklamda Mit Analiz Modeli ile incelenmiştir.

Göstergebilim, her türlü metinde imgelerin ve göstergelerin anlamlarını çözümleyerek anlamın nasıl meydana geldiğini ortaya koymayı amaçlar. Göstergebilim açısından trafik işaretlerinden kıyafetlere, sofra adabından romana, fotoğraftan reklama her şey bir metin, bir söylemdir. Göstergebilimin temel çözümleme birimi olan gösterge, başka bir şeyi çağrıştırarak iletişimi mümkün kılar. Gösterge bir kelime, bir ses veya görsel bir imge olabilir. Gösterge; gösteren ve gösterilen olmak üzere iki unsurdan meydana gelir. Gösteren; harfler, ses, görüntü gibi göstergenin algılanan yanıdır. Gösterilen ise göstergenin zihnimizde oluşturduğu imge, kavram ya da anlamdır. Reklam açısından baktığımızda reklamı yapılan ürün gösteren, ürünün vadettiği şey ise gösterilendir. Örneğin reklamlarda konforun göstergesi arabada uyuyan bir bebek, aşkın göstergesi tek taş yüzük olarak sunulabilir. Bunu sağlayan ise nesne ile duygu arasında kurulan bağlantı yani göstergelerin anlamlandırılmasıdır.

Modern toplumlarda reklamın, geleneksel toplumlardaki efsanelerin doğası ve işlevine benzeyen mitsel bir boyutu vardır. Göstergebilimin betimlediği moda, spor, yemek, reklam gibi sistemler aracılığıyla dünyayı anlamlandırmayı sağlayan mitler (Coward ve Ellis, 1985: 51) insan davranışı için model oluşturur. Postman'a (1994: 92) göre mit, farkında bile olmadığımız, bilincimizin derinliklerine gömülmüş bir düşünme şeklidir. Göstergebilimi gündelik hayatımızdaki hemen her şeye hakim olan mitlerin analizi ile başlatan Barthes (2014) anlamlandırmanın düz anlam ve yan anlam olmak üzere iki düzeyde gerçekleştiğini söylemektedir. İlk düzey olan düz anlam, göstergenin ne olduğunun zihinsel olarak kavranmasına dayanan bilinen anlamıdır. Yan anlamda ise kültürel ve toplumsal kodlara bağlı olarak göstergeye bir başka anlam ya da değer atfedilir. Yani yan anlam, ima edilen anlamdır. Örneğin bir reklam görselindeki elma, Newton'un yerçekimini keşfetmesini sağlayan elmaya atfen "bilimsellik" ile ya da Pamuk Prenses'in yiyip zehirlendiği elmayı çağrıştıracak şekilde "kıskançlık" ile kodlanabilir. Reklam açıkça söylenen ya da "gösterilen" düzlemde değil, ima edilen "gösterenler"

\footnotetext{
$\dagger$ Türkiye'de ulusal çapta yayın yapan kanallar listesinde yer alan Kanal 7, TV8 ve Beyaz TV'de takip edilen tarihte bu güne özel bir reklam yayınlanmamıştır (https://tr.wikipedia.org/wiki/T\%C3\%BCrkiye\%27de_yay\%C4\%B1n_yapan_televizyon_kanallar\%C4\%B1_listesi).
} 
düzleminde işler. Yani reklamın anlamını asıl kuran, yan anlamdır. Örneğin bir margarin reklamı aslında gösterilen "ürün" düzeyinde değil, anne sevgisini o margarini kullananların daha iyi bir anne olduğu imgesine tahvil ettiği “gösteren” düzeyinde anlamlandırılır. Williamson'a (2001:30) göre reklamı anlamak için nasıl işlediğini çözümlemek gerekir. Reklamı yapılan ürüne ilk aşamada, izleyicide zaten bir anlamı olan bir nesne ya da kişi tarafından değer verilir; sonraki aşama ise ürünün kendisinin bir anlam ifade etmesidir. Önce bir nesne, bir duygunun yerine geçer, sonra reklamdaki ürün o nesnenin yerine geçerek bu duyguyu kendine mal eder. Ancak bu anlamlandırma süreci izleyicinin içinde bulunduğu sosyokültürel, ideolojik ve psikolojik yapıdan bağımsız değildir. Bir başka deyişle anlam, bir göstergede kendiliğinden var olmaz (Günay, 2002: 173). Reklamın hedefi olan kişi, gösteren ile gösterileni birleştirip gösterge haline getirmek için kültürel kodlara yani gönderge sistemine başvurur.

Reklamların çözümlemesinde göstergebilimin temel kavramlarından yola çıkan Chapman (1986) reklam mitlerinin analizi için bir model ortaya koymuştur. Tablo 1'de verilen Chapman'in (1986: 70-73) analiz modelinde reklam, izleyicilerine vaatlerde bulunan bir yap1 olarak kavramsallaştırılır. Vaadin zıddı, problem olarak ve reklamdaki vaatlerin problemleri çözmek üzere konumlandırılması süreci de kısaca mit olarak adlandırılır. Mitin çözümlemesinde 'gösterenler', 'gösterilenler' ve 'gönderge sistemleri' olmak üzere üç temel analitik araçtan faydalanılır. Göstergebilimde gösterge kavramının birer parçası olan gösterenler (signifiers) ile gösterilenler (signifieds) modelde anlamın oluşmasını sağlayan temel iki analitik araçtır. Basılı reklamlarda başlık, metin (görsel ya da yazılı) ve slogan anlamın oluşmasını sağlayan temel gösterenler olarak öne çıkarken görüntülü reklamlarda ise temel gösterenler, imge ile metin ve varsa slogandır. Üçüncü analitik araç olan gönderge sistemleri (referrent systems) ise reklamın temel öğelerinin dayandığı ve bu öğelerin anlamlarını yansıtan temel sosyokültürel kaynaktır.

\section{Mitler}

1. Gösterenler (Reklamda ne gösteriliyor?): İlk aşamada reklamda görünen ile gösterilenlerin anlamı kavramsal olarak ayrıştırılır ve bunun için de öncelikle gösterenler ile gösterilenlerin ayrılması gerekir. Reklamda göstergeler genellikle metaforlar ya da metonimiler (düz değişmece) ile temsil edilir.

2. Gösterilenler (Reklamda görünenler ne anlatıyor?): İkinci aşamada her göstergenin ne çağrıştırdığına bakılır. Çok sayıda gösterilen, aynı tema etrafında toplanarak hikâyenin kurucu öğesi olarak işler.

3. Gönderge Sistemleri (Reklamı yapılan ürün ile kullananların dünyası nasıl?): Gösterenler ile gösterilenlerin bir bütün olarak ürüne ya da kullanıcılarına dair ilettiği mesajlar çözümlenir. 
Vaatler (Reklam izleyiciye ne öneriyor?): Reklamlar ürün, ürünün kullanıcıları ya da marka ile ilgili duygusal ya da bilişsel vaatler ileterek izleyicileri ürünü satın almaya ikna etmeyi amaçlar.

Problemler (Reklam neyi azaltmayı / çözmeyi öneriyor?): Problem ürün ya da ürünü kullananlarla ilgili olabilir. Bu son aşamada reklamın azalttı̆̆ı ya da çözdüğü sorun, gerginlik ve çelişkiler ortaya konulur.

Tablo 1: Reklamda Mit Analiz Modeli

\begin{tabular}{|c|c|c|c|c|c|}
\hline & \multicolumn{3}{|l|}{ MITLER } & \multirow[b]{2}{*}{ VAATLER } & \multirow[b]{2}{*}{ PROBLEMLER } \\
\hline & 1. Gösterenler & 2. Gösterilenler & $\begin{array}{l}\text { 3. Gönderge } \\
\text { Sistemleri }\end{array}$ & & \\
\hline $\begin{array}{l}\text { Ürün ile } \\
\text { ilgili }\end{array}$ & \multicolumn{3}{|c|}{$\begin{array}{l}\text { Bir sosyal/kültürel mit için metafor olarak } \\
\text { kullanılan ürünün rolü }\end{array}$} & $\begin{array}{l}\text { Ürünün olumlu } \\
\text { tarafları }\end{array}$ & $\begin{array}{l}\text { Ürünün } \begin{array}{r}\text { tüketiciye } \\
\text { çağrıştırdığı } \\
\text { tarafları }\end{array} \\
\end{array}$ \\
\hline $\begin{array}{l}\text { Kullanıcı } \\
\text { ile ilgili }\end{array}$ & \multicolumn{3}{|c|}{$\begin{array}{l}\text { Ürünü kullanan kişinin temel vasıfları, ihtiyaçları } \\
\text { ve sosyal konumu gibi özellikleri kısaca mitsel } \\
\text { portresi }\end{array}$} & $\begin{array}{l}\text { Ürünün } \\
\text { kullanıcılarının } \\
\text { olumlu } \\
\text { özellikleri }\end{array}$ & $\begin{array}{l}\text { Ürünün mevcut ya da } \\
\text { potansiyel } \\
\text { kullanıcılarının } \\
\text { olumsuz özellikleri }\end{array}$ \\
\hline
\end{tabular}

Kaynak: (Chapman, 1986: 73)

\section{Reklamların Mit Analizi}

Çalışmada toplam 11 reklam analiz edilmiştir. Reklamı yapılan ürünlerin 3 tanesi mücevher, 2'şer tanesi ulaşım ve elektronik, diğerleri ise alışveriş sitesi, mobilya, banka ve ev tekstilidir. Reklam görselleri ve metinlerindeki mitler, vaatler ve problemler çözümlemeye tabi tutulmuş olup analiz, Tablo 2'de özet olarak sunulmaktadır. Bu üç başlığa dair incelenen reklamların söylemlerinde tekrar eden ya da öne çıkan noktaların ortaya konulması için de reklamda anlamı kuran temel gösterenler olan imge ve metin (görsel) ile yazılı metin ve sloganlar (varsa) incelenmiştir.

Reklamlarda mitsel söylem, göstergenin iki temel öğesi olan gösteren ve gösterilen ile bunları anlamlandırmayı sağlayan gönderge sistemi aracılığıyla kurulmaktadır. Temel gösterenin aşk olduğu reklamlarda gösterilen ise yüzük, çikolata, cep telefonu, kolye gibi bir nesnedir. Reklamlardaki gösterenler ile gösterilen yani aşk ile nesneler arasında bağ kurmayı sağlayan gönderge sistemi ise büyük oranda Sevgililer Günü'dür. Bu günde hediye almak, romantik bir sevgili/eş olduğunu göstermek gibi "yapılması gerekenler" reklamlardaki imgeler vasıtasıyla izleyicilere "gösterilmekte"dir. Örneğin Özdilek reklamında sinirli bir sesle "Ahmet bugün günlerden ne?" diye soran genç kadına, genç erkek tereddütle "Bugün? 14 Şubat." diye karşılık verir. "Bir kere de beni şaşırt Ahmet" diye sevgilisine çıkışan genç kadın, odanın kapısını açtığında yatağın üzerindeki kalpli nevresim takımından yerdeki mumlara, kırmızı güllerden kalpli küçük kırmızı renkli lambalara romantik bir şekilde süslenmiş bir oda ile karşılaşır. "Şaşırtırım hayatım sen iste yeter ki" diyen sevgilisine, ellerini kalbinin üzerinde birleştirip 
oldukça yumuşak bir sesle adını söyleyerek cevap verir genç kadın. Romantizmin sembolleri olarak sunulan kalp, mum ve güller ile donatılmış oda, aşka dair algımızı şekillendiren ve Sevgililer Günü'nde romantizm adına yapılması gereken davranış kalıplarını belirleyen gönderge sisteminin bir parçasıdır. Aşka dair mitik söylem, Maksimum Kart reklamında oyuncu Mert Fırat'ın söylediği şarkıda da yankısını bulmaktadır. İdeal bir sevgili olmak için yapılması gerekenler, şarkının “Tribünü satıp gitmediğim maçlar; yağmur çamur gittiğim yollar var. Telefondan sildirdiği kızlar; tango, salsa gittiğim kurslar; tatlış tatlış bir sürü kur var.” şeklindeki sözlerinde anlatılmaktadır. Şarkının devamında "Yaparsın, sen de yaparsın. İnsan aşktan bihaber, büyük konuşma birader." sözleri ile hemcinslerine seslenen aşık genç erkek "Yap yap ne varsa, kalbine girmenin yoluysa. Gel gel utanma, aşk değer tüm bunlara.” sözleri ile aşka dair tavsiye verir. Erkeğe "yap ne gerekiyorsa" diye seslenen reklamda aşkın göstergesi olarak sunulan davranış ise gül, çikolata, pelüş ayıcık gibi bir nesnenin satın alınmasıdır. Enza Home reklamında da genç bir erkek sevgilisine yine çiçek ve pelüş ayıcık hediye etmektedir. Aşka dair mitsel söylemin diğer bir örneği olan Blue Diamond reklamında, pahalı bir yüzük ile edilen evlenme teklifi romantizmin ve aşkın büyüklügünün göstergesi olarak sunulmaktadır. "Aşık olduğunuz kadına evlenme teklif etmek kolay değil ama ona tek taş yüzük almak çok kolay" sözleri tek taş yüzüğün zorlu evlilik teklifini kolaylaştıracağı algısını yaratmaktadır. "Her kadının hakkı" sloganı ise tek taşlı yüzükle evlilik teklifini, erkek için bir zorunluluğa, kadın için ise bir hakka dönüştürmektedir.

Reklamlardaki vaatler aracılığıyla iyi/ideal/istenen bir sevgili olmanın koşulu bir hediye almaya bağlanmaktadır. Reklam söyleminin temel vaadi, alacağınız hediyenin sevginizi/aşkınızı anlatacağıdır. Örneğin Çiçek Sepeti reklamında kolye, çiçek, pelüş ayıcık, parfüm, çikolata, kemer gibi görseller ile "Aşkını anlatmanın en güzel yolu” olarak sunulan hediyeler arasında, kişiler "Sevdiğine özel hediyeyi" seçmeye çağrılmaktadır. Pırlanta kolye, Ariş ve Zen Pırlanta reklamlarında aşkın sembolü olarak sunulurken Ariş Pırlanta reklamında "Pırlanta ile 1şığını yansıt, göster kendini” sözleri ile kadına güzel görünmenin ve sevildiğini başkalarına göstermenin yolunun pahalı bir mücevherden geçtiği mesajı verilmektedir. Alınan hediye, ne kadar pahalıysa karşıdaki kişi için o kadar değerli olduğunuzu kanıtlayan bir göstergeye dönüşmektedir. Örneğin Pegasus reklamında masa başında bilgisayardan hediye seçmeye çalışan genç bir erkeğin olduğu odaya giren genç bir kadın telefonla konuşmaktadır. Ekranda en klasik Sevgililer Günü hediyesi oyuncak ayı görünmektedir. Telefonda kız arkadaşına (ya da eşine) Sevgililer Günü için hediye olarak ne alabileceğini soran Necip adlı arkadaşına genç kadın "Hödük gibi gidip de oyuncak ayı alma, onun yerine Pegasus hediye kartı al" der. Bunu duyan sevgilisi oyuncak ayı almaktan vazgeçip hemen havayolunun sitesine girer. Sonrasında genç kadın, “Ama sakın ucuz olanını seçme dedim" sözleriyle telefon konuşmasının içeriğini sevgilisine anlatmaktadır. Görünen 
bilgisayar ekranında en ucuz paketi seçmeye hazırlanan erkek bundan da hemen vazgeçer "İyi demişsin hayatım, Necip pintidir çünkü” der. Erkeğin yanına yaklaşıp “Sen ne yapıyorsun?” diye soran genç kadına "Tesadüfün böylesi. Ben de sana Pegasus Sevgililer Günü hediye kartı almıştım. Ona bakıyorum.” diye karşılık verir. Ekrana bakıp buna çok sevinen genç kadın "Sevgilim benim" diyerek erkeğe sarılır. Ne de olsa erkek en pahalı hediye kartını alarak sevgisini ispatlamıştır. Eğer hediye pahalı değilse o zaman da romantik ve farklı olmalıdır. Örneğin "Şimdi her yer kalp, gül, çikolata, pelüş ayıcık dolu. Atlas Global ise herkese yetecek kadar sevgiyle dolu. Sevgililer Günü’nde istediğiniz yere uçun diye bir bilet alana ikincisi hediye” şeklindeki Atlas Global reklamı klasik hediyelerden farklı bir seçenek sunar gibi görünmekte ancak yine de hediye almayı Sevgililer Günü'nün olmazsa olmazı olarak saymaktadır. Reklam metni bir adım daha ileri giderek hediyeyi yani uçak biletini sevgiyle dolu olarak nitelemekte ve insani duygu sevgi ile nesneyi yer değiştirmektedir. Vestel reklamında ise ekranda genç bir erkek görünmekte ve üst sesten “Hey gidi koca yürekli adam. Yürek yedin ve Sevgililer Günü’nde sevgiline küçük ev aleti aldın demek. Alkışlıyoruz seni ve şimdi de ilişkin için saygı duruşu." sözleri duyulmaktadır. Reklamda daha sonra cenaze marşı eşliğinde kırık bir kalp altındaki mezar taşında ilişkinin doğum ve ölüm tarihi görünmektedir. Ölüm tarihi 14 Şubat 2019'dur. Genç erkek, sembolik mezarın başında yas tutmaktadır. Alt yazıda ise "Biz ilişkilere saygımızdan Sevgililer Günü’nde küçük ev aleti satmıyoruz. Daha romantik öneriler için www.vestel.com.tr" yazmaktadır. Reklam her ne kadar ürün ile duygu arasında doğrudan bir bağ kurmuyorsa da sevgili olmaya ve romantizme dair algımızı etkileyen gönderge sisteminin şekillenmesine katkıda bulunmaktadır. Çünkü daha çok mutfakta kullanılan küçük ev aletleri Sevgililer Günü’nde bir erkeğin sevgilisine verebileceği 'romantik' hediye sınıfına girmemektedir.

Reklamlarda çözüm önerilen en önemli problem ise kişinin sevgisini anlatamamasıdır. Tek taş yüzük evlilik teklifini olması gerektiği hale getirerek kabul edilmesini sağlayacak, pırlanta kolye ya da şı oturma grubu sevgilinize (ya da eşinize) sevildiğini gösterecek, tatil için uçak bileti ya da hediye kartı da yine sevgilinize cömert görünmenizi sağlayacaktır. Hepsinin ortak paydası ise aşkın tüketim nesnelerinden geçerek anlatılabileceği ya da gösterilebileceği söylemini desteklemeleridir. Örneğin Samsung reklamının "Sevginiz hala taze ama telefonunuz eskiyse, değiştirin. Aşkınız parlasa da fotoğraflarınız karanlık çıkıyorsa değiştirin” şeklindeki metni, aşkı taze ve parlak tutmanın yolunun nesnelerden geçtiğini söylemektedir. Enza Home reklamı ise her ne kadar "önemli olan ona sevdiğinizi söylemenizdir" dese de şık mobilyalar ile dolu bir ev, sevgiyi anlatmak için daha uygun bir ortam olarak sunulmaktadır. 
Karadeniz Sosyal Bilimler Dergisi, İlkbahar 2021, Y. 13, S. 24, s. 17-35

Tablo 2: Reklamların Mit Analizi

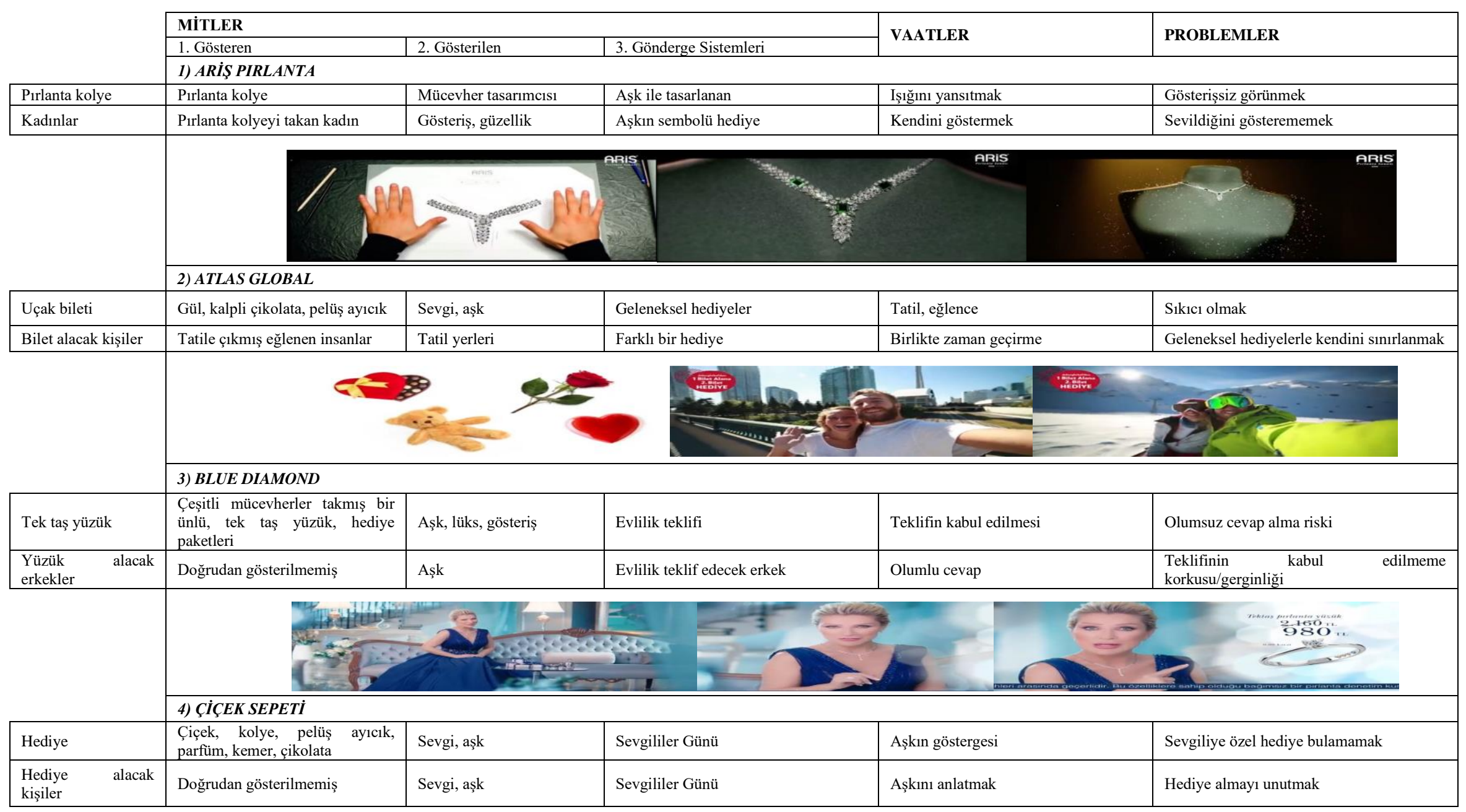


Elif ŞEŞEN

14 Şubat Sevgililer Günü Televizyon Reklamlarının Göstergebilimsel Çözümlemesi

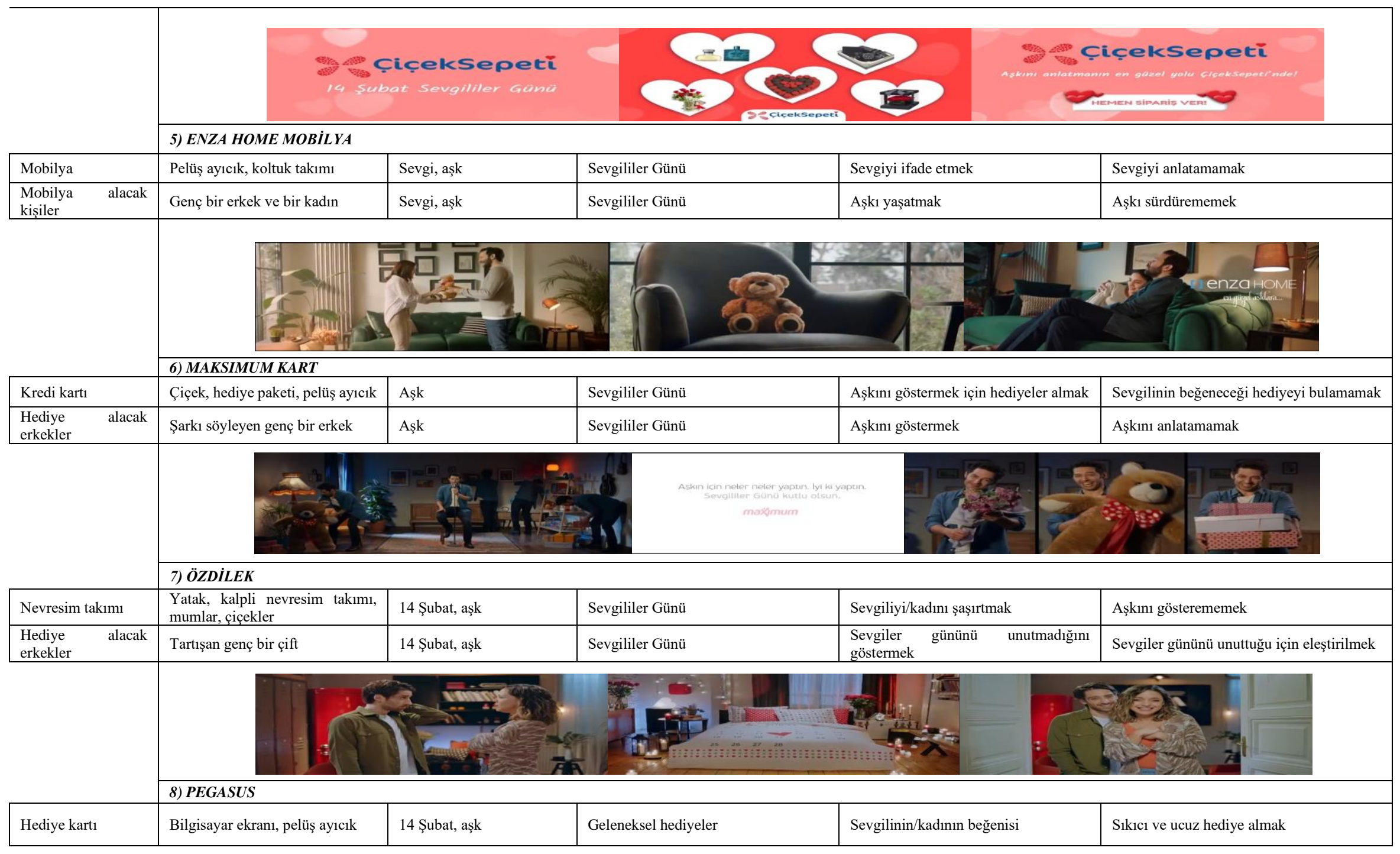


Karadeniz Sosyal Bilimler Dergisi, İlkbahar 2021, Y. 13, S. 24, s. 17-35

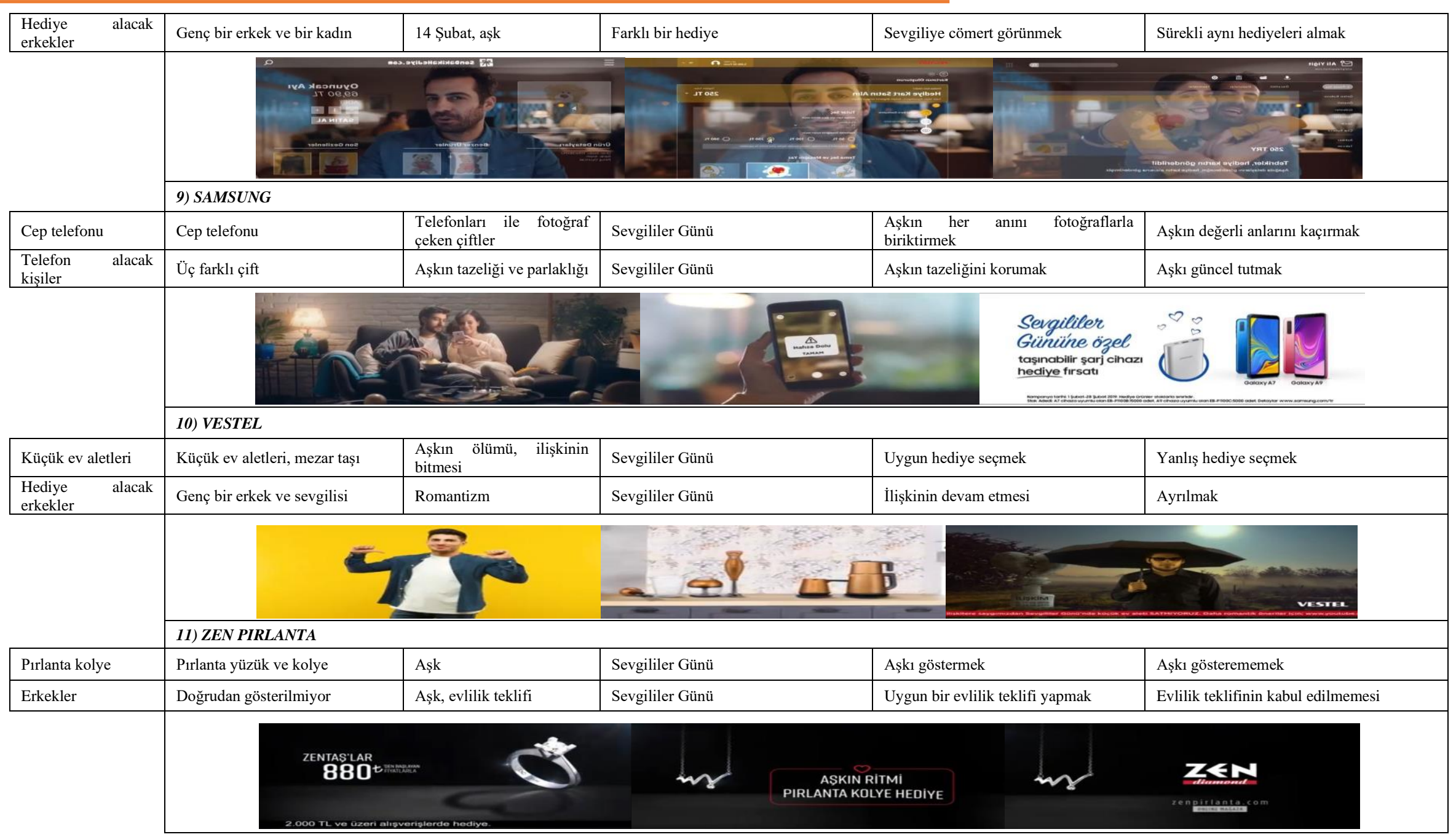




\section{Sonuç}

Tüm dünyada ve ülkemizde markaların satış artırmada Yılbaşı, Sevgililer Günü, Anneler Günü, Babalar Günü gibi özel tarihlerden faydalanmaya çalışması daha sık görülen bir uygulama haline gelmiştir. Reklamlar ile bu günlerin özel ve önemli olduğu yönünde yeni bir hayat tarzı ve bu günlere özel hediye alınması gerektiği fikri yerleştirilmeye çalışır. Hıristiyan bir rahibin idamla sonuçlanan hazin hayat hikayesi etrafında oluşturulan bir mitin, nasıl iyi kurgulanmış bir eski zaman aşk masalına dönüştürüldüğünün örneği olan Sevgililer Günü, içine ustaca yerleştirilen "sevdiğine hediye vererek mutlu etme" motifi sayesinde kârlı bir satış stratejisi haline gelmiş ve hızla küreselleşmiştir.

Kişilerin tüketime çağrılmasını ve satın almaya ikna edilmesini insani duygu ve ilişkiler ile nesneler arasında bağ kurarak bir başka deyişle nesneleri birer göstergeye dönüştürerek başaran reklam söylemi, bunun için çeşitli gönderge sistemlerinden faydalanır. Önce gösteren ile gösterileni birbirine bağlayan, daha sonra da kişiler için bir değer ya da anlam ifade eden gösterilene dair duygu ve düşüncelerimizi gösterene aktaran reklam, izleyicisinin bu iki öğeyi zihninde birleştirerek gösterge haline getirebilmesi ve istendik yönde anlamlandırabilmesi için başvuracağı gönderge sisteminin de temel taşlarını dizmeye katkıda bulunur. Böylece mum ışığında akşam yemeği romantizmin ya da tek taş yüzük aşkın sembolü haline gelir. Bu anlamlandırma süreci, izleyicide inşa edilen mitler sayesinde işlemektedir.

2019 yılında Sevgililer Günü’nden bir gün önce yani 13 Şubat 2019 tarihinde ulusal televizyon kanallarında yayınlanan reklamları, göstergebilimden yola çıkarak çözümlemeyi amaçlayan bu çalışma, reklam söyleminin aşka ve tüketime dair mitsel söylemini incelemektedir. Çalışma kapsamında incelenen Sevgililer Günü için özel olarak hazırlanmış reklamlarda, mitsel aşk söylemini kuran gönderge sistemi, bu günde "yapılması" ve "yapılmaması" gerekenlere dair yerleştirilmeye çalışılan davranış kalıplarına dayanmaktadır. Reklamlarda çözümü önerilen temel problem sevgiyi gerektiği gibi gösterememek, temel vaat ise Sevgililer Günü’nde alınacak hediyenin aşkın göstergesi olduğudur.

Reklamların cinsiyetçi bir söylemi de vardır. Çünkü alıcı olarak genellikle erkeğe seslenir. Blue Diamond, Enza Home, Özdilek, Pegasus, Vestel, Zen Pırlanta reklamlarında hedef alıcının erkek olduğu çeşitli imge ya da ifadeler ile belli edilmektedir. Örneğin Enza Home reklamında hediye ayıcık erkeğin elindedir, Özdilek reklamında sevgilisine sürpriz yapan erkektir. Pegasus reklamında hediye alan ya da Vestel reklamında ilişkinin devamı için doğru hediyeyi alması gereken de erkektir. Close ve Zinkhan'ın (2006) çalışmasında tek taş yüzük, çiçek ya da akşam yemeği gibi Sevgililer Günü’ne has olarak kabul gören hediyelerin kadının erkekten beklediği şeyler olduğu ifade edilmektedir. Atar ve arkadaşlarının (2016) çalışmasında da en fazla dergi reklamı yapılan 14 Şubat hediyelerinin başında erkeklerin alması beklenen pahalı mücevherlerin geldiğine dikkat çekilmektedir. Bir başka deyişle reklamı yapılan ürünler cinsiyetçi kalıpları yansıtmaktadır.

Örneklemin genelleme yapmaya yetersiz olmasının yanı sıra çalışma kapsamında incelenen reklamların izleyici gözünden de analizinin eksik oluşu çalışmanın temel sınırlılıklarıdır. Farklı 
çalışmalarla, reklam mesajlarının anlamlandırılmasını sağlayan gönderge sistemlerinin kültürel, tarihsel, psikolojik ve sosyolojik olarak daha geniş bir perspektifle incelenmesi reklamların yerleştirmeye çalıştığı mitsel söylemin ortaya konulması açısından faydalı olacaktır.

\section{Kaynaklar}

Adalı Aydın, G. (2016). Popüler Kültür ve Reklam İlişkisi: Basılı Reklamlarda 14 Şubat Sevgililer Günü. Global Media Journal TR Edition, 6 (12), 387-410.

Akay, A. (1999). Armağan. İstanbul: Bağlam Yayınları.

Arık, M. B. (2004). Bir Kültür Endüstrisi Ürünü Olarak 14 Şubat Sevgililer Günü. İstanbul Üniversitesi İletişim Fakültesi Dergisi, 20 (1), 79-87.

Atar, M., Şener, G. ve Onay, A. (2016). Aşkın Metafor Hali: Sevgililer Günü Kapsamında Kadın ve Erkek Dergilerindeki Reklamlarda Aşkın Sunumu. Global Media Journal TR Edition, 6 (12), 411-433.

Aydin, D. ve Akcan, B. (2017). Love Monitoring: Analysis of Valentine's Day Advertisements. Intermedia International Journal, Spring, 4 (6), 110-119.

Barthes, R. (1998). Anlatıların Yapısal Çözümlemelerine Giriş. (Çev.: Mehmet Rıfat ve Sema Rıfat). İstanbul: Gerçek.

Barthes, R. (2014). Çağdaş Söylenler. (T. Yücel, Çev.). İstanbul: Metis.

Baudrillard, J. (2004). Tüketim Toplumu. (Çev.: Nilgün Tutal ve Ferda Keskin). İstanbul, Ayrınt1 Yayınları.

Baudrillard, J. (2013). Üretimin Aynası. (O. Adanır, Çev.). İstanbul: Boğaziçi Üniversitesi Yayınevi.

Baudrillard, J. (2014). Nesneler Sistemi. (O. Adanır ve A. Karamollaoğlu, Çev.). İstanbul: Boğaziçi Üniversitesi Yayınları.

Bauman, Z. (1997). Özgürlük. (K. Eren, Çev.). İstanbul: Sarmal Yayınları.

Bauman, Z. (2014). Sosyolojik Düşünmek. (A. Yılmaz, Çev.). İstanbul: Ayrıntı.

Bayhan, V. (2011). Tüketim Toplumunda Bireyin Ontolojik Mottosu: "Tüketiyorum Öyleyse Varım”. Sosyoloji Konferansları Dergisi, 43, 221-248.

Bocock, R. (1997) Tüketim. (İ. Kutluk, Çev.). Ankara: Dost Kitabevi.

Brosius, C. (2010). Love in the Age of Valentine and Pink Underwear: Media and Politics of Intimacy in South Asia. Springer (Eds. C. Brosius \& R. Mandoki), Transcultural Turbulences (pp. 2766). Berlin.

Büyükdüvenci, S. (2001). Modern ve Postmodern ‘Aşk’ İkilemi. Doğu Batı, Sayı 15, 169-172.

Calesta, K. (2006). Valentine's Day. Teen Ink, 17 (6), 18-24.

Canöz, N. (2015). Kültür Endüstrisi Ürünü Olarak 14 Şubat Sevgililer Günü. Selçuk Üniversitesi Sosyal Bilimler Enstitüsü Dergisi, 34, 135-143.

Chapman, S. (1986). Great Expectorations: Advertising and the Tobacco Industry. London: Comedia.

Close, A. ve Zinkhan, G. M. (2006). A holiday loved and loathed: A consumer perspective of Valentine's Day. Advances in Consumer Research, 33, 356-365.

Coward, R. ve Ellis, J. (1985). Dil ve Maddecilik. (E. Tarım, Çev.). İstanbul: İletişim Yayınları.

Çubuklu, Y. (2007). Kurgular ve Cinsiyetçilik. İstanbul: Everest Yayınları.

Debord, G. (1996). Gösteri Toplumu. (A. Ekmekçi ve O. Taşkent, Çev.). İstanbul: Ayrıntı. 
Dyer, G. (2010). İletişim Olarak Reklamcılık. (N. Öncel, Çev.). İstanbul: Beta.

Erdoğan, İ. ve Alemdar, K. (2005). Popüler Kültür ve İletişim. Ankara: Erk Yayınları.

Ersoy, E. (2008). Tarihsel Kapitalizmden Güncel Kapitalizme Küreselleşme. Ankara: Doğu Anadolu Bölgesi Araştırmaları.

Featherstone, M. (1996). Postmodernizm ve Tüketim Kültürü. (M. Küçük, Çev.). İstanbul: Ayrıntı.

Gülmez, M. ve Önder, S. S. (2006). Beynelmilel. https://www.imdb.com/title/tt0893507/.

Günay, D. (2002). Göstegebilim Yazıları. İstanbul: Multilingual.

Kimura, J. ve Belk, R. W. (2005). Christmas in Japan: Globalization versus localization. Consumption, Markets and Culture, 8 (2), 325-338.

Kocabaş, F. ve Elden, M. (2004). Reklamcılık. İstanbul: İletişim Yayınları.

Kozanoğlu, C. (1995). Pop Çağı Ateşi. İstanbul: İletişim Yayınları.

Kükrer, Ö. (2010). Reklamda Mitler ve Anlam. Akdeniz Üniversitesi İletişim Fakültesi Dergisi, 13 (1), $25-43$.

Lasch, C. (2006). Narsisizm Kültürü. (S. Öztürk ve Ü. Yolsal, Çev.). Ankara: Bilim ve Sanat Yayınları.

Lefebvre, H. (1998). Modern Dünyada Gündelik Hayat. (I. Gürbüz, Çev.). İstanbul: Metis Yayınları.

Marshall, G. (2005). Sosyoloji Sözlüğü. (O. Akınhay ve D. Kömürcü, Çev.). Ankara: Bilim ve Sanat Yayınları.

Marshall, M. N. (1996). Sampling for Qualitative Research. Family Practice, 13(6), 522-526.

Mauss, M. (1954). The Gift: Forms and Functions of Exchange in Archaic Societies. London: Cohen and West.

Miller, G. (2010). Sevişen Beyin: Eş Bulma Süreci İnsan Doğasını Nasıl Belirledi? (M. Asım Karaömerlioğlu, Çev.). İstanbul: NTV Yayınları.

Minowa, Y., Khomenko, O. ve Belk, R. W. (2011). Social Change and Gendered Gift-Giving Rituals: A Historical Analysis of Valentine's Day in Japan. Journal of Macromarketing, 31(1), 44-56.

National Retail Federation (NRF). Annual 2019 Valentine's Day Spending Survey (2019) https://nrf.com/media-center/press-releases/fewer-consumers-celebrating-valentines-daythose-who-do-are-spending.

Odabaşı, Y. (2006). Tüketim Kültürü İstanbul: Sistem Yayıncılık.

Postman, N. (1994). Televizyon: Öldüren Eğlence. (O. Akınhay, Çev.). İstanbul: Ayrıntı.

Postman, N. (2006). Teknopoli: Yeni Dünya Düzeni. (M. E. Yılmaz, Çev.). İstanbul: Paradigma Yayıncilik.

Rugimbana, R., Donahay, B., Neal, C. ve Polonsky, M. (2003). The role of social power relations in gift giving in Valentine's Day. Journal of Consumer Behaviour, 3 (3), 63-73.

Rupp, K. (2003). Gift-giving in Japan: Cash, Connections, Cosmologies. Stanford, CA: Stanford University Press.

Schopenhauer, A. (2011). Aşkın Metafiziği: Aşka ve Kadınlara Dair. (A. Aydoğan, Çev.). İstanbul: Say Yayınları.

Siddiqui, T. (2016). Media Coverage of Valentine's Day: Is Media Biased in Covering the Festival? International Journal of Social Sciences, 3 (3), 171-187.

Şeker, A. (2019). Hediye ve Hediye Satın Alma Davranışları. Afyon Kocatepe Üniversitesi Sosyal Bilimler Dergisi, 21 (3), 869-887. 
Topay, G., Erdem, R. (2019). Türkiye'de Tüketim Kültürünün Gelişimine Dair Kavramsal Bir İnceleme. Süleyman Demirel Üniversitesi Sosyal Bilimler Enstitüsü Dergisi, 35 (3), 162-183.

Ünalan, D. Ve Doğan, Ş. (2019). Globalization and Media: Dissemination of Culture Through Media. Akademisyen Kitabevi (G. Topçu \& A. D. Topçu (Eds.), Communication Studies (pp 1-24). Ankara.

Vannini, P. (2004). Will You Marry Me? Spectacle and Consumption in the Ritual of Marriage Proposals. Popular Culture, 38 (1), 169-185.

Wernick, A. (1996). Promosyon Kültürü: Reklam, İdeoloji ve Sembolik Anlatım. (O. Akınhay, Çev.). Ankara: Bilim ve Sanat Yayınları.

Williamson, J. (2001). Reklamların Dili: Reklamlarda Anlam ve İdeoloji. (A. Fethi, Çev.). Ankara: Ütopya.

Yı1dız, N. (2013). Aşk Yüzyı1ı Bitti. İstanbul: Doğan Kitap.

Zorlu, A. (2003). "Batılı Bir Yaşam Tarzı Olarak Tüketim: Türkiye'de Tüketim Ürünlerinin ve Kültürünün Tarihi Gelişimi”. Hacettepe Üniversitesi Sosyolojik Araştırmalar e-Dergisi. www.sdergi.hacettepe.edu.tr/makaleler/zorlu_makale.pdf.

https://www.youtube.com/watch?v=1qI0PxM6Wdc (Erişim tarihi: 25.07.2020). https://www.youtube.com/watch?v=1Rb0IxuAP_M (Erişim tarihi: 25.07.2020). https://www.youtube.com/watch?v=9j2e8Ljui5E (Erişim tarihi: 25.07.2020). https://www.youtube.com/watch?v=b6bAn5jP8SE (Erişim tarihi: 25.07.2020). https://www.youtube.com/watch?v=e5UaUynafBg (Erişim tarihi: 25.07.2020). https://www.youtube.com/watch?v=iY_1EyyetWk (Erişim tarihi: 25.07.2020). https://www.youtube.com/watch?v=PFA8rmQAaco (Erişim tarihi: 25.07.2020). https://www.youtube.com/watch?v=qPeQqxe8NxQ (Erişim tarihi: 25.07.2020). https://www.youtube.com/watch?v=v3j_Owr28no (Erişim tarihi: 25.07.2020). https://www.youtube.com/watch?v=v3j_Owr28no (Erişim tarihi: 25.07.2020). https://www.youtube.com/watch?v=yfyBhobKmco (Erişim tarihi: 25.07.2020). 